Book Review: Port Operations, Planning and Logistics.

Book Author(s): Khalid Bichou

Review Author(s): Mary R. Brooks

Source: Journal of the Transportation Research Forum, Vol. 49, No. 3 (Fall 2010), p. 155-156

Published by: Transportation Research Forum

Stable URL: http://www.trforum.org/journal

The Transportation Research Forum, founded in 1958, is an independent, nonprofit organization of transportation professionals who conduct, use, and benefit from research. Its purpose is to provide an impartial meeting ground for carriers, shippers, government officials, consultants, university researchers, suppliers, and others seeking exchange of information and ideas related to both passenger and freight transportation. More information on the Transportation Research Forum can be found on the Web at www.trforum.org. 
Bichou, Khalid. Port Operations, Planning and Logistics. Lloyd's Practical Shipping Guides. London: Informa, 2009. ISBN 978-1-84311-805-3.

\title{
Port Operations, Planning and Logistics
}

\author{
by Mary R. Brooks
}

By its title, the book promises a reader a solid tome on a subject of considerable practitioner interest. The marketing material suggests that this coverage will be "a comprehensive and detailed analysis" drawing on "established multi-disciplinary academic expertise." The table of contents confirms that we will be introduced to a wide variety of port topics of interest to the practicing port manager. For the most part, they are all here. In fact, the major contribution of this book is its comprehensive coverage and its multi-disciplinary approach. The author is to be lauded for the ambitious coverage he seeks to offer in this book.

Where this book excels are the two topics in which the author has done considerable research and consulting - benchmarking and port security. In these chapters, the text goes from the bigger picture to greater depth, and provides citations to the work of others, drilling down to the level expected by a seasoned academic reader. We also see evidence of why a port manager might choose one alternative over another, which approaches are more useful for a particular situation, and other such useful information for practitioners. Two potential audiences for the book will be engaged in these chapters.

One topic that is of keen interest to both managers and governments and not sufficiently dealt with is the topic of concessions, arising from financial securitization of terminal operations. Chapter 4 includes this topic under a short section entitled port financing and private sector participation. As global terminal operators consolidated their grasp on the management of container terminal operations over the past decade and more, the issue of concessions (or leases in North America) became extremely important. Port authorities did not want to give too much, terminal operators wanted to be sure their risks were manageable and remunerative, and governments wanted to be sure that they did not lose control of strategic assets, that the assets owned by taxpayers were being appropriately managed, and that return to the public purse was acceptable. A few examples of concessions are supplied, and the figures are informative, but the accompanying text barely scratches the surface of this very important topic. This is one topic where more would have been better, and more explanation is mandatory if a second edition is written.

As for port strategies, however, we are provided with the generic rather than the creative or innovative. It would have been of interest to this particular reader to have a well-developed discussion of how ports approach their long-term thinking on acquiring new business, retaining old, and deciding on whether to follow co-operative, competitive, or co-opetitive strategies. This, too, is a suggestion for the second edition.

The author, Khalid Bichou, is a well-known and widely recognized port consultant; a book of his should be of considerable interest to both practitioners and scholars. This would have been a better publication if the author had focused on those areas where his depth of knowledge could have been shared with the reader and his understanding of why particular decisions are made in certain ports and not others.

Where this book struggles is in defining its target audience. It reads like a textbook, with lists and illustrative figures, but fails as a textbook because it does not adequately explain many of the tables or figures; there is no glossary of words or acronyms or additional readings for each chapter. Furthermore, the list of additional readings is mixed with the bibliography and is not topic-specific. Students must not be its target audience. It is written, in part, like a scholarly tome but it does 
not meet the level of sourcing and citation expected of a serious academic work. So many tables, thoughts, and ideas are not adequately attributed to those who originally developed the ideas. From a scholarly perspective, the depth of coverage is uneven. Given these two off-target audiences, we must assume that its target audience is only the practitioner, hence its appearance in the Practical Shipping Guides list.

In summary, this book delivers a comprehensive, high-level overview but at a price that narrows its target audience. Although it is written like a textbook, the cost being charged by the publisher (US\$441 not including duties or taxes) is sufficiently prohibitive that it will not be adopted as a text except for a rare course targeting industry executives. I can only assume that, given its price, the target audiences are library directors who will feel they must buy the book, scholars in the field of port economics whose libraries might pay the price or practitioners whose port coffers are rich enough to pay the price. While the first does not have the expertise to evaluate the value of the book beforehand, the second will be interested in the theoretical and practical content, but the last will not necessarily follow the economic models that it occasionally presents. Therefore, while the content will be of considerable interest to a limited number of practitioners, it will not provide them with the detailed value-added they seek for the price. In other words, this book appears to miss its possible audiences, mostly because of a poor pricing decision by the publisher. It is written for the student but only affordable by a few practitioners. Given this, it seems unlikely there will be demand for a second edition. That is a shame given the need for the book in the textbook market.

Dr. Mary R. Brooks is the William A. Black Chair of Commerce at Dalhousie University. She has an undergraduate degree from McGill University, an M.B.A. in international business (Dalhousie University), and a Ph.D. in maritime studies (University of Wales). She is currently a Professor of Marketing and Transportation at Dalhousie University. Since 1979 she has held various teaching and research appointments at Dalhousie University, including research associate positions with the Dalhousie Ocean Studies Programme, the Canadian Marine Transportation Centre, and the Oceans Institute of Canada. Her latest book investigating trade in transportation services in North America was published by Edward Elgar in July 2008. Past service includes president of the Canadian Transportation Research Forum (1990-91). 